\title{
Selective Determination of Uranium Using 1-(2-Quinolylazo)- 2,4,5-Trihydroxybenzene as a Colorimetric Reagent
}

\author{
PRATAP SINGH KADYAN ${ }^{\mathrm{a}^{*}}$, SAPANA GARG ${ }^{\mathrm{a}}$, \\ DEVENDER SINGH $^{\mathrm{a}}$ and SONIA VERMA ${ }^{\mathrm{b}}$
}

${ }^{a}$ Department of Chemistry, Maharshi Dayanand University, Rohtak-124001, India

${ }^{\mathrm{b}}$ Department of Chemistry, A.I. J.H.M College, Rohtak-124001, India

pskadyan@rediffmail.com

Received 15 September 2012 / Accepted 20 October 2012

\begin{abstract}
Colorimetric reaction behavior of 1-(2-quinolylazo)-2,4,5-trihydroxybenzene (QATB) has been established with uranium(VI) under various physicochemical conditions. An addition of dilute solution of uranyl ions to the dimethylformamide (DMF) solution of QATB, resulted to form a brown colored complex which was soluble if 30\% DMF concentration was maintained. The brown colored complex absorbing maximum at $560 \mathrm{~nm}$ in the $\mathrm{pH}$ range 6.5-7.5. Beer's law was valid over

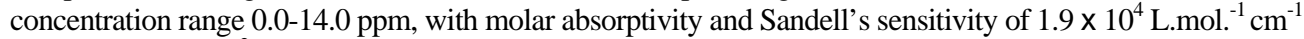
and $0.0125 \mu \mathrm{g} \mathrm{cm}^{2}$, respectively. The molar composition of the complex was 1:2 (M:L) as determined by Job's method of continuous variation. The tolerance limits for interfering ions are discussed. All variables were studied in order to optimize the reaction conditions. The efficiency of the proposed method is shown by the successful determination of traces of uranium in some ores.
\end{abstract}

Keywords: Spectrophotometry, QATB, Uranium, Ores

\section{Introduction}

It is well known that uranium is toxic as well as being radioactive; the safety profiles for uranium compounds are well established ${ }^{1,2}$. Because uranium is a relatively mobile element in many surface or near-surface environments, its geochemical exploration methods require the measurement of the trace quantities of the metal ion in water samples ${ }^{3,4}$, along with that in plants, soils and rocks. The uranium concentration of sea water is about $3.3 \mu \mathrm{g} / \mathrm{L}^{4,5}$ in fresh-water or even lower. Thus, highly sensitive methods are required for pre-concentration and determination of uranium in water samples collected for prospecting purposes.

Numerous method for the spectrophotometric determination of uranium based on the use of balmic acid, morin, sodium fluoride, pyrogallol red, pyrogallic acid etc., have been reported $^{6-13}$, but most of them require a solvent extraction step and entail various disadvantages in terms of reproducibility, simplicity, rapidity and sensitivity. Heterocyclic azo compounds have attracted much attention as they are sensitive chromogenic reagents in addition to being important complexing agents. These dyes have been useful in the spectrophotometric determination due to its good selectivity and sensitivity over a wide range of $\mathrm{pH}$ and because they are relatively easy to synthesize and purify. 
This paper reports, 1-(2-quinolylazo)-2,4,5-trihydroxybenzene (QATB) as an analytical reagent for the micro determination of uranium(VI), whereas a very limited number of heterocyclic azo dyes find their uses for the determination of uranium(VI). Comparatively this reagent has been found a selective reagent for uranium(VI).

\section{Experimental}

A Bausch and Lomb Spectronic 2000 spectrophotometer with $10 \mathrm{~mm}$ matched glass cells was used for recording spectra and a Beckman $\mathrm{pH}$ meter was used for $\mathrm{pH}$ measurements.

\section{Reagents and solutions}

All the chemicals were of analytical grade. Doubly distilled water was used throughout the experiment for the dilution of the reagents and samples. Standard uranium(VI) solution of uranyl ion was prepared by dissolving appropriate amount of uranyl nitrate (AnalaR) in double distilled water. The solution was standardized as uranyl oxinate ${ }^{14}$.

1-(2-Quinolylazo)-2,4,5-trihydroxybenzene (QATB) as synthesized earlier ${ }^{15}$, was used as a $1 \times 10^{-3} \mathrm{M}$ solution prepared by dissolving $0.281 \mathrm{~g}$ of freshly distilled dimethyl-formamide (DMF). Solutions more than a week old were discarded. Dilute solution of sodium hydroxide, sodium acetate and hydrochloric acid were prepared and used for $\mathrm{pH}$ adjustment.

\section{Determination of uranium(VI)}

To a suitable volume of sample containing 20.0-120.0 $\mu \mathrm{g}$ of uranyl ions, $2 \mathrm{~mL}$ of $2 \times 10^{-3} \mathrm{M}$ QATB solution in DMF was added followed by addition of $2 \mathrm{~mL}$ of $1 \times 10^{-3} \mathrm{KCN}$ solution. $1.0 \mathrm{~mL}$ of $1 \mathrm{M}$ sodium acetate was added and made up the volume to $10 \mathrm{~mL}$, maintaining $40 \%$ DMF concentration in the final solution. The absorbance at $560 \mathrm{~nm}$ was measured against a corresponding reagent blank prepared under similar conditions.

\section{Results and Discussion}

Uranyl ions formed a light brown colored precipitates with an ethanolic solution of QATB. The precipitate was not soluble up to 70\% ethanolic concentration. However, DMF solution of QATB also resulted to form a brown colored complex with uranyl ions which was soluble if $30 \%$ DMF concentration was maintained. The color reaction was therefore studied in $40 \%$ DMF. The absorbance spectra of $\mathrm{UO}_{2}(\mathrm{II})$-QATB complex solution maintaining 40\% DMF concentration recorded against corresponding reagent blank (QATB solution without metal ion) solution are shown in Figure 1. The complex had constant and maximum absorbance in the $\mathrm{pH}$ range of 6.5-7.5. For maintaining an appropriate $\mathrm{pH}$ of the complex solution $1 \mathrm{~mL}$ of $1 \mathrm{M}$ sodium acetate was sufficient. For attaining maximum sensitivity, at least 5-times molar excess of reagent was required and hence in subsequent studies, 10-times molar excess of reagent was used. Under these optimum conditions, various physicochemical constants were established and are given in Table 1. A comparative study of the sensitivities of various spectrophotometric reagents known for uranium given in Table 2, shows, that the present reagent has a good sensitivity for the micro determination of uranium.

\section{Effect of diverse ion}

In the determination of uranium(VI) at the $4.76 \mu \mathrm{g} / \mathrm{mL}$ level; chloride, bromide, iodide, nitrite, sulphate, sulphite, alkaline earths, lanthanides, aluminum(III), indium(III), antimony(III), bismuth(III), chromium(III), platinum metals (except palladium(II)) did not interfere at all. However, thorium(IV) and rare earths up to 1000 fold do not interfere in the determination. EDTA and borax were found to interfere. Under the appropriate conditions found for uranium(VI), cyanide and iodide are tolerated in fair concentration and have been used to mask of interfering transition metals. 


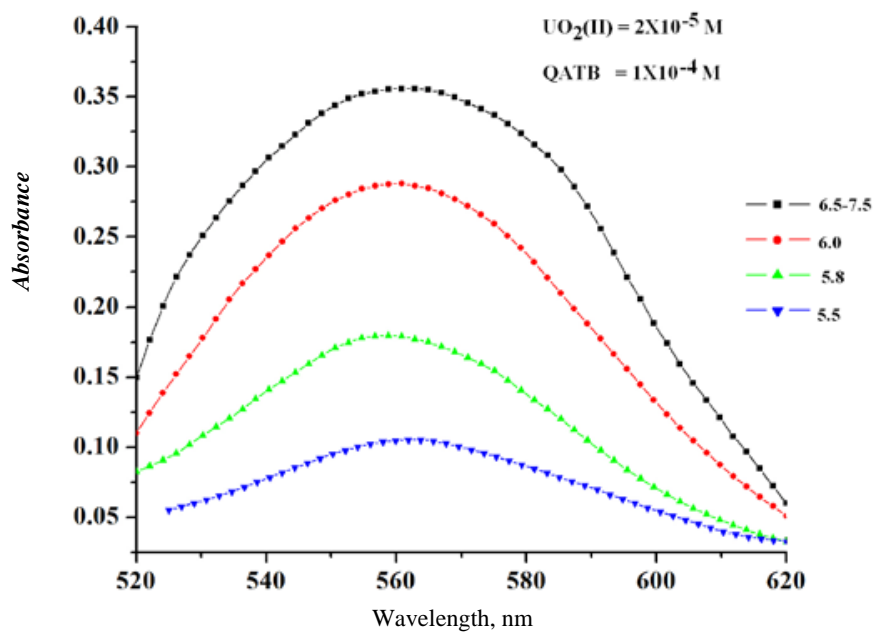

Figure 1. Absorption spectra of $\mathrm{UO}_{2}$ (II)-QATB complex at different $\mathrm{pH}$

Table 1. Physicochemical characteristics of $\mathrm{UO}_{2}(\mathrm{II})$-QATB complex

\begin{tabular}{lc}
\hline Characteristics & $\mathrm{UO}_{2}(\mathrm{II})-\mathrm{QATB}$ complex \\
\hline$\lambda_{\max }, \mathrm{nm}$ & 560 \\
$\mathrm{pH}$ range & $6.5-7.5$ \\
Reagent required for full complexation, mol & 5 \\
Beer's law range, $\mathrm{ppm}$ & $0.00-14.0$ \\
Sandell's sensitivity, $\mu \mathrm{g} \mathrm{cm}^{-2}$ & 0.0125 \\
Molar absorptivity $(\epsilon), \mathrm{l} \mathrm{mol}^{-1} \mathrm{~cm}^{-1}$ & $1.9 \times 10^{4}$ \\
Composition (M:L) by job's method & $1: 2$ \\
Optimum concentration range, ppm & $2.0-12.0$ \\
\hline
\end{tabular}

Table 2. Comparison of sensitivities of various spectrophotometric reagents for uranium(VI)

\begin{tabular}{lccc}
\hline \multicolumn{1}{c}{ Reagent } & $\begin{array}{c}\lambda_{\max }, \\
\mathrm{nm}\end{array}$ & $\begin{array}{c}\text { Molar absorptivity, } \\
\text { L.mol } \mathrm{Cm}^{-1}\end{array}$ & References \\
\hline $\begin{array}{l}\text { 2-Hydroxy-3-methoxybenzaldehyde } \\
\text { isonicotinoyl hydrazone }\end{array}$ & 374 & $1.05 \times 10^{4}$ & 16 \\
2-(2-Thiazolylazo)-p-cresol & 588 & $1.31 \times 10^{4}$ & 17 \\
Pyrocatechol violet & 650 & $9.5 \times 10^{4}$ & 18 \\
1,4-Dihydroxy-9,10- anthracenedione & 600 & $1.19 \times 10^{4}$ & 19 \\
--Chlorophenyl fluorone & 560 & $1.42 \times 10^{4}$ & 20 \\
5-(p-Carboxyphenylazo)-8- hydroxyquinoline & 470 & $4.39 \times 10^{4}$ & 21 \\
5-(2- Carboxyphenylazo)-8-quinolinol & 524 & $1.035 \times 10^{4}$ & 22 \\
5,14- $N, N^{\prime}$ - Hydroxyphenyl - 4, 15-dioxo- & 390 & $1.0 \times 10^{4}$ & 23 \\
1,5,14,18-tetraazo hexacosane & & & \\
2-Hydroxy-1-naphthaldehyde isonicotinoyl & 430 & $9.6 \times 10^{3}$ & 24 \\
hydrazone & & & \\
Di-2-pyridyl ketone benzoyl hydrazone & 377 & $2.02 \times 10^{4}$ & 25 \\
Diacetyl monoxime isonicotionyl hydrazone & 364 & $1.63 \times 10^{4}$ & 26 \\
1-(2-Quinolylazo)-2,4,5-trihydroxybenzene & 560 & $1.9 \times 10^{4}$ & This work \\
\hline
\end{tabular}


Uranium(VI) can therefore be determined selectively in presence of many base metals as well as noble metals. Table 3 represents the tolerance limits in ppm of various ions in solution that caused a deviation smaller than $\pm 2 \%$ in absorbance for the determination of uranium(VI).

Table 3. Tolerance limits of diverse ions in the determination of $4.76 \mu \mathrm{g} / \mathrm{mL}$ of uranium(VI)

\begin{tabular}{|c|c|c|}
\hline Foreign ions & Tolerance limits, ppm & Masking agents \\
\hline $\mathrm{F}^{-}$ & 50 & - \\
\hline $\mathrm{Cl}^{-}$ & 600 & - \\
\hline $\mathrm{Br}^{-}$ & 600 & - \\
\hline $\mathrm{I}^{-}$ & 500 & - \\
\hline $\mathrm{CNS}^{-}$ & 200 & - \\
\hline $\mathrm{CN}^{-}$ & 100 & - \\
\hline $\mathrm{S}_{2} \mathrm{O}_{3}{ }^{2-}$ & 400 & - \\
\hline Oxalate & 20 & - \\
\hline Citrate & 20 & - \\
\hline Tartrate & 20 & - \\
\hline $\mathrm{PO}_{4}{ }^{3-}$ & 50 & - \\
\hline Mo(VI) & 25 & - \\
\hline $\mathrm{W}(\mathrm{VI})$ & 10 & - \\
\hline $\mathrm{V}(\mathrm{V})$ & 20 & Masked by $\mathrm{CN}^{-}$ \\
\hline Cd(II) & 40 & - \\
\hline Hg(II) & 40 & - \\
\hline Mn(II) & 10 & - \\
\hline $\mathrm{Fe}(\mathrm{II})$ & 10 & Masked by $\mathrm{CN}^{-}$ \\
\hline $\mathrm{Cu}(\mathrm{II})$ & 5 & Masked by CN- \\
\hline Zn(II) & 4 & - \\
\hline Ag(II) & 10 & Masked by I' \\
\hline Pd(II) & 20 & Masked by I'- \\
\hline $\mathrm{Pb}(\mathrm{II})$ & 20 & Masked by $\mathrm{CN}^{-}$ \\
\hline
\end{tabular}

\section{Application for determining uranium(VI) in various synthetic ores}

Synthetic mixtures of the ores were prepared by mixing the compounds in the same ratio equivalent to the composition of the corresponding ore and dissolving them in concentrated $\mathrm{HCl}$. The mixture were evaporated to dryness and dissolved in distilled water. The amount of U(VI) was determined following the recommended procedure given above. Synthetic mixtures of important alloys used for various purposes were prepared by mixing appropriate amounts of components and were also analyzed following the recommended procedure. The results of the analysis are given in Table 4 .

Table 4. Estimation of uranium(VI) in synthetic samples of uranium ores

\begin{tabular}{|c|c|c|c|c|c|}
\hline Ores/ Alloys & $\begin{array}{l}\text { Amount of uranium } \\
\text { taken, ppm or } \\
\text { (\% composition in ore) }\end{array}$ & $\begin{array}{l}\text { Uranium(VI) } \\
\text { found, ppm }\end{array}$ & $\begin{array}{c}\text { Mean } \\
\text { value, } \\
\text { ppm }\end{array}$ & $\begin{array}{c}\% \\
\text { Recovery }\end{array}$ & $\begin{array}{c}\text { Standard } \\
\text { Deviation }(\sigma)\end{array}$ \\
\hline Pitchblende & $\begin{array}{l}\mathrm{U}(\mathrm{VI}) \text { 47, } \mathrm{Pb}(\mathrm{II}) \text { 3.0, } \\
\mathrm{As}(\mathrm{II}) \text { 0.9, Ca(II) 0.5 }\end{array}$ & $\begin{array}{l}46.7,46.8, \\
47.5,46.5 . \\
48.0,47.3\end{array}$ & 47.133 & 100.28 & 0.568 \\
\hline Monazite & $\begin{array}{l}\mathrm{U}(\mathrm{VI}) \text { 48, } \mathrm{Pb}(\mathrm{II}) 3.5 \text {, } \\
\mathrm{As}(\mathrm{II}) 1.2, \mathrm{Ca}(\mathrm{II}) 1.0\end{array}$ & $\begin{array}{l}48.5,48.8, \\
47.7,47.5, \\
48.4,48.6\end{array}$ & 48.25 & 100.52 & 0.524 \\
\hline
\end{tabular}




\begin{tabular}{cccccc}
\hline Carnotite & $\mathrm{U}(\mathrm{VI}) 52$, & $52.5,52.7$, & & & \\
$\mathrm{K}_{2}\left(\mathrm{UO}_{2}\right)_{2}\left(\mathrm{VO}_{4}\right)_{2}$. & $\mathrm{K}(\mathrm{I}) 9.0, \mathrm{~V}(\mathrm{~V}) 12$ & 51.4 .52 .6$, & 52.166 & 100.32 & 0.572 \\
$1-3 \mathrm{H}_{2} \mathrm{O}$ & $51.5,52.3$ & & & \\
\hline Autunite & $\mathrm{Ca}(\mathrm{II}) 5.0$, & $53.0,52.7$, & & & \\
$\mathrm{Ca}\left(\mathrm{UO}_{2}\right)_{2}\left(\mathrm{PO}_{4}\right)_{2}$. & $\mathrm{U}(\mathrm{VI}) 52.0$ & $51.4,51.6$, & 52.333 & \multirow{2}{*}{100.64} & 0.668 \\
$10-12 \mathrm{H}_{2} \mathrm{O}$ & & $52.5,52.8$ & & & \\
\hline Torbernite & $\mathrm{U}(\mathrm{VI}) 48.0$, & $\begin{array}{l}48.8,49.0, \\
47.5,47.3,\end{array}$ & & & \\
$\mathrm{Cu}\left(\mathrm{UO}_{2}\right)_{2}\left(\mathrm{PO}_{4}\right)_{2}$. & $\mathrm{Cu}(\mathrm{II}) 6.4$ & $48.5,48.4$ & & \multirow{2}{*}{100.52} & 0.695 \\
$10 \mathrm{H}_{2} \mathrm{O}$ & & & & \\
\hline
\end{tabular}

\section{Conclusion}

It has been demonstrated that QATB is an excellent analytical reagent for the spectrophotometric determination of Uranium(VI) in ores/alloys samples. QATB is more simple, sensitive and cheap than most other reagents reported earlier. Nearly all anions and most of the cations do not interfere with the chromogenic reaction. Under the appropriate conditions found for Uranium(VI), cyanide and iodide are tolerated in fair concentration and have been used to mask of interfering transition metals. The colour reaction is fast and the complex is stable which makes it easy to obtain accurate and precise results.

\section{References}

1. Domingo J L, in: Corn M W, (Ed.), Handbook of Hazardous Materials, Academic Press, London, 1993, 705.

2. Lewis R J, Sax's Dangerous Properties of Industrial Materials, Van Nostrand Reinhold, New York, 1996.

3. Miyake Y, Sugimara Y and Mayeda M, J Oceanogr Soc Jpn., 1970, 26, 123.

4. Shannon S S, The HSSR Program and its Relation to the Nure Effort Symposium on Hydrogeochemical and Stream sediment Reconnaissance for Uranium in the United State, Grand Junction, CO, 1977.

5. $\quad$ Aziz M, Beheir S G and Shakin K, J Radional Nucl Chem., 1993, 172, 319.

6. $\quad$ Gupta K K, Kulkarni P G and Singh R K, Talanta, 1993, 40, 507.

7. Nakashima T, Yoshimura K and Taketatsu T, Talanta, 1992, 39, 523.

8. $\quad$ Mori I, Fujita Y and Kato K, Talanta, 1989, 36, 688.

9. Hung S C, Qu C L and Wu S S, Talanta, 1982, 29, 629.

10. Coronel F T, Mareva S and Yordanov N, Talanta, 1982, 29, 119.

11. Bunus F T, Talanta, 1977, 24, 629.

12. Navratil O, Radiokhimiya, 1977, 19, 626-641.

13. Akhmedli M K, Ayubova A M and Azimova S R, Zhurnal Neorganicheskoi Khimii., 1976, 21, 188.

14. Vogel A I, A Text Book of Quantitative Inorganic Analysis, Longman Press, London, 1975, 540.

15. Singh I and Poonam, Talanta, 1984, 31, 109.

16. Rao M R, Hari K, Devanna N and Chandrashekhar K B, Asian J Chem., 2008, 20(2), 1402.

17. Teixeira L S G, Costa A C S, Ferreira S L C, Freitas M D L and Carvalho M S D, $J$ Braz Chem Soc., 1999, 10(6), 519.

18. Park C I, Huang H Z and Cha K W, Bull Korean Chem Soc., 2001, 22(1), 84.

19. Agnihotri N K, Singh V K and Singh H B, Analyst, 1995, 120, 1809-1814.

20. Cui K Y and Zeng F, Fenxi Shiyanshi, 2000, 19, 34. 
21. $\quad$ Li Y, Ying M, Ying X, Long X and Jianyan L, Huaxue Fence, 1996, 32, 145.

22. Saran R and Baishya N K, J Radioanal Nucl Chem., 1995, 196, 363.

23. Agrawal Y K, Shrivastav P and Menon S K, Sep Purif Technol., 2000, 20, 177-183.

24. Vijaya Kumari D and Lakshiminarayana K, J Radioanal Nucl Chem., 1993, 175.

25. Abu-Eid M, Zatar N A, Al-Nuri M A, Khamis M, Hannoun M and Khalaf S, AnNajah J Res., 1994, 2(8).

26. Reddy G C, Devanna N and Chandrasekhar K B, Orbital Elec J Chem., 2011, 3(1), 24. 